\title{
Energy balance, nitrogen balance, and growth in preterm infants fed expressed breast milk, a premature infant formula, and two low-solute adapted formulae
}

\author{
O G BROOKE, C WOOD, AND J BARLEY
}

Department of Child Health, St George's Hospital, London

SUMMARY Energy balance, nitrogen balance, and growth studies were done in 37 preterm infants (20 of very low birthweight) who were fed on expressed breast milk or on one of 3 formulae each of $\frac{N}{\infty}$ different composition, including a special premature formula and a highly adapted 'humanised' $\infty$ formula. The variability of breast milk composition was such that it would have been difficult to 은 predict the infants' protein and energy intakes under normal nursing conditions. All measured parameters of nutritional performance were best in infants fed on the 'premature' formula and were $\varnothing_{\mathbb{D}}$ reflected in greater weight gain, linear growth, and head growth. The nitrogen balance data suggest that the highly adapted formula, which had a protein content comparable with that of mature human milk, contained too little protein for small preterm infants.

Although much has been written and spoken about the feeding of preterm infants, there is no agreement on what is best. Current opinion probably favours breast milk ${ }^{1-4}$ but this is not supported by strong evidence that it is better than, or even as good as, specially adapted cows' milk formulae as a source of nutrients for the very immature. The arguments for using human milk are based on work on its immunological and anti-infective properties, ${ }^{56}$ on the prevention of necrotising enterocolitis, ${ }^{7}$ on the greater biological suitability of its proteins, ${ }^{2}$ on improved fat absorption, ${ }^{8}$ and on psychological and emotional factors. The available data do not make a convincing case because no long-term differences in outcome favouring breast milk have been demonstrated. Possibly even the reverse is true, if the preliminary finding ${ }^{9}$ can be confirmed, that the development of very small infants fed banked human breast milk is less satisfactory than that of similar infants fed a premature formula. In the short term there may be nutritional problems with human milk. Its composition is variable, 1011 and it may be deficient in energy, protein, minerals, and trace elements. ${ }^{12-16}$ Such deficiencies can on occasion limit growth and prevent the infant from thriving. ${ }^{914}$ The studies described here were designed to investigate energy and nitrogen balance, the aspects of nutrition most obviously connected with growth, in preterm infants fed with human milk and cows' milk-base formulae. The formulae selected were a moder $\nexists$ low-solute adapted milk with a low protein content, a more traditional infant formula with higher protein content, and a special 'premature' formula.

\section{Patients and methods}

Infants. Details of the 37 infants studied are given in 3 Table 1. Gestation was confirmed by Dubowitz's method $^{17}$ if in doubt, but most had early ultrasound dating. All infants were well at the time that they were studied. None had significant malformations. 을 Twenty were of very low birthweight $(<1500 \mathrm{~g})$. 윽 Twenty-one were small for gestational age, defined as having a birthweight $<10$ th centile for gestational $O$ age using Gairdner's charts. ${ }^{18}$ This reflects the practice of the obstetric unit, which acts as a referral 옹 centre for complicated pregnancies. In most cases $D$ the fetal growth retardation was the result of . pre-eclampsia, essential hypertension, or placental $N$ abruption. Seven infants were studied more than o once. To compare the different feeds, infants were $N$ matched for birthweight, gestation, and age at time స్ట of study (see page 901). Measurements were made 으 during a total of 71 weeks, on average 2 weeks per 0 baby. Informed parental consent was obtained and $\frac{}{\Phi}$ the studies were approved by the hospital's ethical $\stackrel{?}{?}$ committee. 
Table 1 Details of infants studied

\begin{tabular}{|c|c|c|c|c|}
\hline Gender & $\begin{array}{l}\text { Birthweight } \\
\text { (g) }\end{array}$ & $\begin{array}{l}\text { Gestation } \\
\text { (weeks) }\end{array}$ & $\begin{array}{l}\text { Age at study } \\
\text { (days) }\end{array}$ & $\begin{array}{l}\text { Mean weight } \\
\text { at study }(g)\end{array}$ \\
\hline $\mathbf{F}$ & 890 & 26 & 53 & 1370 \\
\hline $\mathbf{F}$ & $1000^{*}$ & 33 & 24 & 1110 \\
\hline $\mathbf{F}$ & 1040 & 28 & 34,43 & 1590,1830 \\
\hline $\mathbf{F}$ & $1040^{*}$ & 32 & 17 & 1340 \\
\hline $\mathbf{M}$ & $1050^{*}$ & 32 & 20,33 & 1520,2090 \\
\hline $\mathbf{F}$ & 1110 & 29 & 20 & 1920 \\
\hline $\mathbf{F}$ & $1120^{*}$ & 30 & 20 & 1280 \\
\hline $\mathbf{F}$ & $1160^{*}$ & 32 & 17 & 1210 \\
\hline $\mathbf{F}$ & $1160^{*}$ & 33 & 17 & 1260 \\
\hline $\mathbf{M}$ & $1190^{*}$ & 32 & 7,25 & 1190,1630 \\
\hline $\mathbf{M}$ & $1200^{*}$ & 32 & 21 & 1530 \\
\hline $\mathbf{F}$ & 1210 & 31 & $24,38,56$ & $1320,1600,1850$ \\
\hline $\mathbf{F}$ & $1220^{*}$ & 33 & 13,28 & 1270,1590 \\
\hline $\mathbf{F}$ & $1260^{*}$ & 32 & 28 & 1560 \\
\hline $\mathbf{F}$ & 1260 & 28 & 16 & 1360 \\
\hline $\mathbf{F}$ & $1280^{*}$ & 34 & 8 & 1360 \\
\hline $\mathbf{F}$ & 1340 & 31 & 12 & 1310 \\
\hline $\mathbf{F}$ & $1380^{*}$ & 34 & 15 & 1740 \\
\hline $\mathbf{F}$ & $1480^{*}$ & 35 & 11 & 1760 \\
\hline $\mathbf{M}$ & $1540^{*}$ & 34 & 15,24 & 1820,2160 \\
\hline $\mathbf{M}$ & $1540^{*}$ & 34 & 11 & 1670 \\
\hline $\mathbf{M}$ & $1540^{*}$ & 35 & 13 & 1870 \\
\hline $\mathbf{F}$ & $1540^{*}$ & 34 & 13 & 1540 \\
\hline $\mathbf{F}$ & 1600 & 31 & 15 & 1780 \\
\hline F & $1630^{*}$ & 35 & 5 & 1650 \\
\hline $\mathbf{F}$ & 1650 & 34 & 27 & 1930 \\
\hline $\mathbf{M}$ & 1680 & 33 & 6 & 1705 \\
\hline $\mathbf{F}$ & $1700^{*}$ & 36 & 14 & 1920 \\
\hline $\mathbf{M}$ & 1700 & 32 & 17 & 1960 \\
\hline $\mathbf{F}$ & 1700 & 32 & 13 & 1780 \\
\hline $\mathbf{F}$ & 1780 & 30 & 25 & 1870 \\
\hline $\mathbf{M}$ & 1790 & 32 & 17,24 & 1950,2160 \\
\hline $\mathbf{M}$ & $1860^{*}$ & 35 & 7 & 2020 \\
\hline $\mathbf{F}$ & 2300 & 32 & 8 & 2170 \\
\hline $\mathbf{M}$ & $2000^{*}$ & 35 & 5 & 1980 \\
\hline $\mathbf{F}$ & 1460 & 31 & 17 & 1530 \\
\hline \multirow[t]{2}{*}{$\mathbf{M}$} & 1720 & 32 & 25 & 1850 \\
\hline & $1436 \pm 317$ & \multicolumn{2}{|c|}{$32 \cdot 3 \pm 2 \cdot 2 \quad 20 \pm 11$} & $1665 \pm 290$ \\
\hline
\end{tabular}

* $<$ 10th weight centile. ${ }^{18}$

Feeding and study design. Most infants of very low birthweight had an initial period of partial or total parenteral feeding. Thereafter they were fed intragastrically, either continuously or by hourly gavage at the start, later working up to 3-hourly gavage. A few of the larger infants were studied after they had achieved partial or full bottle feeding but tube feeding was used throughout the balances in most of them. Enteral feeding was begun either with expressed breast milk (EBM) or with the low protein formula (Osterfeed, see page 900), depending on the availability of breast milk and the mother's wishes. Thereafter selection of the feed for study was determined solely by the need to match the groups of infants for birthweight, gestation, and postnatal age. The study feed was begun 1-2 weeks after the infant had been established on full enteral feeding, and was receiving an intake of at least $180 \mathrm{ml} / \mathrm{kg}$ daily. Data on matching of the infants are shown in Tables 2 and 3. Random allocation was not considered feasible because of the fairly small numbers of suitable infants and the effects of gestational age and birthweight on postnatal digestive function and growth, ${ }^{19} 20$ which make matching mandatory unless

Table 3 Details of matching for gestation and postnatal age in all infants studied

\begin{tabular}{|c|c|c|c|c|}
\hline & Pre-Aptamil & Osterfeed & $E B M$ & Milumil \\
\hline $\begin{array}{l}\text { Gestation (weeks) } \\
\text { Postnatal age (days) }\end{array}$ & $\begin{array}{l}34 \\
15\end{array}$ & $\begin{array}{l}34 \\
15\end{array}$ & $\begin{array}{l}34 \\
11\end{array}$ & \\
\hline $\begin{array}{l}\text { Gestation (weeks) } \\
\text { Postnatal age (days) }\end{array}$ & $\begin{array}{l}28 \\
48\end{array}$ & $\begin{array}{l}26 \\
51\end{array}$ & $\begin{array}{l}28 \\
43\end{array}$ & \\
\hline $\begin{array}{l}\text { Gestation (weeks) } \\
\text { Postnatal age (days) }\end{array}$ & $\begin{array}{l}32 \\
25\end{array}$ & $\begin{array}{l}33 \\
28\end{array}$ & $\begin{array}{l}32 \\
28\end{array}$ & $\begin{array}{l}32 \\
22\end{array}$ \\
\hline $\begin{array}{l}\text { Gestation (weeks) } \\
\text { Postnatal age (days) }\end{array}$ & $\begin{array}{r}35 \\
5\end{array}$ & $\begin{array}{r}35 \\
7\end{array}$ & $\begin{array}{l}36 \\
12\end{array}$ & $\begin{array}{l}53 \\
10\end{array}$ \\
\hline $\begin{array}{l}\text { Gestation (weeks) } \\
\text { Postnatal age (days) }\end{array}$ & $\begin{array}{l}32 \\
20\end{array}$ & $\begin{array}{l}33 \\
18\end{array}$ & $\begin{array}{l}33 \\
24\end{array}$ & $\begin{array}{l}31 \\
13\end{array}$ \\
\hline $\begin{array}{l}\text { Gestation (weeks) } \\
\text { Postnatal age (days) }\end{array}$ & $\begin{array}{l}32 \\
17\end{array}$ & $\begin{array}{l}32 \\
13\end{array}$ & $\begin{array}{l}31 \\
15\end{array}$ & $\begin{array}{l}32 \\
25\end{array}$ \\
\hline $\begin{array}{l}\text { Gestation (weeks) } \\
\text { Postnatal age (days) }\end{array}$ & $\begin{array}{l}32 \\
17\end{array}$ & $\begin{array}{l}32 \\
17\end{array}$ & $\begin{array}{l}30 \\
20\end{array}$ & $\begin{array}{l}31 \\
25\end{array}$ \\
\hline $\begin{array}{l}\text { Gestation (weeks) } \\
\text { Postnatal age (days) }\end{array}$ & $\begin{array}{r}33 \\
7\end{array}$ & $\begin{array}{r}32 \\
7\end{array}$ & $\begin{array}{r}34 \\
8\end{array}$ & \\
\hline $\begin{array}{l}\text { Gestation (weeks) } \\
\text { Postnatal age (days) }\end{array}$ & & $\begin{array}{l}32 \\
32\end{array}$ & $\begin{array}{l}32 \\
27\end{array}$ & \\
\hline $\begin{array}{l}\text { Gestation (weeks) } \\
\text { Postnatal age (days) }\end{array}$ & $\begin{array}{l}35 \\
11\end{array}$ & $\begin{array}{l}35 \\
13\end{array}$ & & \\
\hline $\begin{array}{l}\text { Gestation (weeks) } \\
\text { Postnatal age (days) }\end{array}$ & $\begin{array}{l}34 \\
34\end{array}$ & $\begin{array}{l}24 \\
27\end{array}$ & & \\
\hline
\end{tabular}

Table 2 Matching for gestational age, birthweight, and age at time of study in the 4 groups of infants

\begin{tabular}{|c|c|c|c|c|c|}
\hline & $\begin{array}{l}\text { Number of } \\
\text { infants }\end{array}$ & $\begin{array}{l}\text { Birthweight } \\
(g) \pm S D\end{array}$ & $\begin{array}{l}\text { Gestation (weeks) } \\
-S D\end{array}$ & $<$ lOth centile & $\begin{array}{l}\text { Age at study (days) } \\
\pm S D\end{array}$ \\
\hline $\begin{array}{l}\text { Pre-Aptamil } \\
\text { Osterfeed }\end{array}$ & $\begin{array}{l}10 \\
10\end{array}$ & $\begin{array}{l}1337 \pm 265 \\
1381 \pm 299\end{array}$ & $\begin{array}{l}32 \cdot 8 \pm 1 \cdot 9 \\
32 \cdot 6 \pm 2 \cdot 6\end{array}$ & $\begin{array}{l}8 \\
8\end{array}$ & $\begin{array}{l}19 \cdot 4 \pm 10 \cdot 1 \\
19 \cdot 3 \pm 13 \cdot 8\end{array}$ \\
\hline $\begin{array}{l}\text { Pre-Aptamil } \\
\text { EBM }\end{array}$ & $\begin{array}{l}9 \\
9\end{array}$ & $\begin{array}{l}1267 \pm 276 \\
1304 \pm 252\end{array}$ & $\begin{array}{l}32 \cdot 3 \pm 1 \cdot 8 \\
32 \cdot 3 \pm 2 \cdot 3\end{array}$ & $\begin{array}{l}7 \\
7\end{array}$ & $\begin{array}{l}21 \cdot 3 \pm 11 \cdot 1 \\
19 \cdot 4 \pm 8 \cdot 4\end{array}$ \\
\hline $\begin{array}{l}\text { EBM } \\
\text { Osterfeed }\end{array}$ & $\begin{array}{l}8 \\
8\end{array}$ & $\begin{array}{l}1328 \pm 313 \\
1318 \pm 266\end{array}$ & $\begin{array}{l}32 \cdot 1 \pm 2 \cdot 7 \\
32 \cdot 4 \pm 2 \cdot 5\end{array}$ & $\begin{array}{l}6 \\
6\end{array}$ & $\begin{array}{l}19 \cdot 1 \pm 15 \cdot 2 \\
19 \cdot 3 \pm 8 \cdot 9\end{array}$ \\
\hline Milumil & 5 & $1536 \pm 306$ & $32 \cdot 2 \pm 1 \cdot 6$ & 3 & $19 \cdot 0 \pm 8 \cdot 4$ \\
\hline
\end{tabular}


unrealistically large numbers are studied. We elected not to use a crossover design, which would have increased the numbers, because of difficulties in ensuring that the design was balanced and because of the necessarily shortened period during which an infant could be studied on any one feed.

Composition of feeds. Infants were fed on pasteurised* EBM (generally the mother's own but occasionally supplemented by banked EBM), Osterfeed (Farley Health Products, Plymouth), Milumil (Milupa Ltd, Hillingdon), or Pre-Aptamil (Milupa Ltd). Osterfeed is a cows' milk-based, low-solute, highly adapted infant formula. It is recommended for the formula feeding of term infants but is also used for feeding preterm infants in neonatal units in the UK. Milumil is a more 'traditional' cows' milk-based infant formula with higher protein and mineral content than Osterfeed, although the composition meets the ESPGAN criteria for formula feeds for neonates. ${ }^{21}$ Pre-Aptamil is a special premature formula adapted to meet the theoretical requirements for increased protein, energy, and minerals. ${ }^{22}$ Details of the composition of the formulae are given in Table 4 . All were given as ready-to-feed liquid preparations. The total energy content of the formulae was determined by ballistic bomb calorimetry. ${ }^{23}$ Their nitrogen content was analysed by the Kjeldahl technique using a semiautomated method. The breast milk was analysed for total energy and nitrogen during each balance. The energy content of the breast milk ranged from 49 to 76 (mean $64 \pm 8$ ) $\mathrm{kcal} / 100 \mathrm{ml}$ and its nitrogen content from 173 to 390 (mean $276 \pm 76) \mathrm{mg} / 100 \mathrm{ml}$.

Balances. Energy and nitrogen balances were performed during 3 days between carmine markers,

* 30 minutes at $65^{\circ} \mathrm{C}$.

Table 4 Composition of the formulae (per $100 \mathrm{ml}$ ) fed to the infants

\begin{tabular}{lccc}
\hline & Osterfeed & Milumil & Pre-Aptamil \\
\hline Energy (kcal) & 68 & 68 & 76 \\
Protein (g) & $1 \cdot 45$ & $1 \cdot 85$ & $2 \cdot 1$ \\
Protein energy (\% of total) & 9 & 11 & 11 \\
Whey:casein ratio & $61: 39$ & $20: 80$ & $55: 45$ \\
Carbohydrate (g) & $6 \cdot 96^{*}$ & $8 \cdot 4 \dagger$ & $8 \cdot 7^{*}$ \\
Fat (g) & $3 \cdot 8 \ddagger$ & $3 \cdot 1 \ddagger$ & $3 \cdot 6 \S$ \\
Total minerals (g) & $0 \cdot 19$ & $0 \cdot 29$ & $0 \cdot 3$ \\
Sodium (mg) & 19 & 27 & $38 \cdot 5$ \\
Potassium (mg) & 57 & 86 & $94 \cdot 0$ \\
Calcium (mg) & 36 & 71 & $67 \cdot 0$ \\
Phosphorus (mg) & 31 & 55 & $47 \cdot 0$ \\
Magnesium (mg) & 5 & 7 & $7 \cdot 8$ \\
Osmolality (mOsmol/kg) & 283 & 342 & 374 \\
\hline
\end{tabular}

* Lactose.

†Lactose $6 \%$, maltodextrin $1.3 \%$, amylase $1.1 \%$.

†Cows' milk fat and vegetable oils.

§Cows' milk fat and vegetable oils, no MCT. and were done between 4 and 10 days after the $\rho$ start of the study feed. Intakes were weighed. Small $\frac{\overline{0}}{.}$ vomits were collected on weighed absorbent pads $\vec{\Rightarrow}$ for later analysis and subtraction from the intake. $\stackrel{\oplus}{+}$ No infant with clinically significant vomiting was studied. Excreta were collected in preweighed $\frac{\bar{\sigma}}{\bar{n}}$ disposable napkins (Redinaps, Robinsons of $\frac{\bar{\omega}}{\widehat{D}}$ Chesterfield, Wheat Bridge, Chesterfield, Derbyshire) $\stackrel{\mathbb{D}}{\AA}$

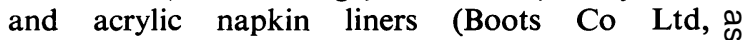
Nottingham). Special care was taken to ensure that $\vec{\bullet}$ the napkins fitted closely round the waist and thighs to prevent leakage. The liners retain the stool and $\vec{\omega}$ allow the urine to pass through into the absorbent $\stackrel{\sigma}{\sigma}$ napkin. Although this does not give complete separation of faeces and urine, such separation is not $?$ essential for input/output balances. However the isolation of the faeces by this method is good ${ }^{24}$ and $\vec{N}$ the results obtained for faecal and urinary nitrogen $\%$ are very similar to those found in other studies $\infty$ on preterm infants in which urine was collected 9 separately. ${ }^{25} 26$ At each napkin change, all stool was carefully removed from the buttocks and placed with the liner in a sealed polyethylene bag, as was the napkin containing urine. Each was promptly frozen at $-20^{\circ} \mathrm{C}$ in a freezer kept in the unit. Stools were subsequently weighed, with subtraction for the weight of the liner, and freeze-dried. After thoroug homogenisation they were analysed for energy b ballistic bomb calorimetry, in quadruplicate of quintuplicate, and for nitrogen by the Kjeldaht technique in duplicate.

Urine volume was calculated from the weight of the napkins, which were then separated from their $\stackrel{\mathbb{Q}}{\varrho}$ plastic backing and pulped in a bucket containing a $\overrightarrow{\vec{P}}$ known volume of water (allowed for in the calculations). After thorough mashing, the homogenate was filtered through a large vacuum funnel and aliquots were freeze-dried for bomb calorimetry and the Kjeldahl nitrogen analysis. Water blanks were used to ensure that no nitrogen was recoverable from $:$ unsoiled napkins. Vomit pads were treated in the 3 . same way as the urine, and their calculated energy $\delta$ and nitrogen content was subtracted from the intake 3 for the day. Digestible energy was defined as dietary energy minus faecal energy. Fat absorption coefficient was defined as dietary fat - faecal fat/faecal fat $\times 100$. Nitrogen retention was defined as dietary $\mathbf{N}$ minus urine and faecal $\mathbf{N}$.

Growth measurements. All infants were weighed daily to the nearest $10 \mathrm{~g}$ increment on a well-calibrated beam balance (Marsden Weighing Machines, London). Weight gains were expressed as $\mathrm{g} / \mathrm{kg}$ a day, where the denominator was the mean body weight over the measurement period. The following twice weekly measurements were also made: (1) Crown-to-heel 
length, to the next succeeding $\mathrm{mm}$ on a horizontal stadiometer. ${ }^{27}$ (2) Upper arm length, to the next succeeding $\mathrm{mm}$, measuring from the shoulder to the flexed elbow with a caliper. ${ }^{28}$ (3) Occipito-frontal head circumference, to the next succeeding $\mathrm{mm}$ using a paper tape trimmed to exact zero. (4) Midupper arm circumference, using paper tape in the same way as for head circumference and taking particular care not to compress the tissues. (5) Biceps, triceps, and subscapular skinfolds, ${ }^{29}$ using a Harpenden caliper (British Indicators Limited), the readings being taken when the jaws had ceased contracting on the fold. (6) Upper arm fat area ${ }^{30}$ was calculated from mid-upper arm circumference, biceps, and triceps skinfold using the formula: fat area $=$ arm area minus lean area, where: lean area $=\frac{1}{4 \pi}\left[\right.$ arm circumference $-\frac{\pi}{2}$ (triceps + biceps skinfold)]. ${ }^{2}$

Metabolic monitoring. Weekly measurements of urea, electrolytes, and acid base status were made and urine specific gravity was monitored.

Analysis of results. Data on energy and nitrogen balance in preterm infants are likely to be skewed because of the effects of the varying degree of immaturity. However the study design ensured adequate pair matching between infants fed on Pre-Aptamil and those fed on Osterfeed and EBM (Tables 2 and 3). The results for these 3 feeds were therefore compared using Student's $t$ test. Fewer infants were studied on Milumil because this formula was not particularly well tolerated by preterm infants. However, the mean gestation and age at study in this group did not differ from the other groups, so the results of Milumil feeding were compared with the others in the same way. Because standards for intrauterine growth in weight, length, and head circumference are available ${ }^{1831}$ the postnatal increments in these measurements in our infants were compared as a percentage of the 50th centile of an intrauterine standard during the same postconceptional age period. These results are expressed as coefficients of weight, length, and head growth. Growth rates the same as the intrauterine standard are expressed as unity, and greater or lesser rates as positive or negative percentages of the standard rate.

\section{Results}

Table 5 shows the results of intake, outputs, balances, and the growth measurements made during the study periods in the 4 groups of infants, and Table 6 gives the comparisons which reached statistical significance. There was no significant difference in the volumes of feed per $\mathrm{kg}$ given daily to the infants in each group, hence energy intake was higher in the group fed Pre-Aptamil than in the other groups, since Pre-Aptamil has a higher energy density.

There was rather poor fat absorption on Milumil but energy digestibility and retentions were similar

Table 5 Intake, output, balance, and growth data in the 4 groups of infants (mean $\pm S D)$

\begin{tabular}{|c|c|c|c|c|}
\hline & $\begin{array}{l}E B M \\
(11 \text { infants })\end{array}$ & $\begin{array}{l}\text { Pre-Aptamil } \\
\text { (10 infants) }\end{array}$ & $\begin{array}{l}\text { Osterfeed } \\
\text { (11 infants) }\end{array}$ & $\begin{array}{l}\text { Milumil } \\
\text { (5 infants) }\end{array}$ \\
\hline 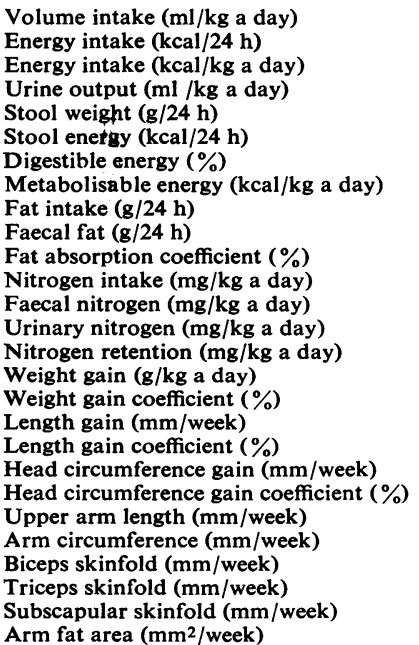 & $\begin{array}{c}205 \pm 7 \\
210 \pm 53 \\
136 \pm 17 \\
131 \pm 19 \\
13 \cdot 2 \pm 8 \cdot 0 \\
48 \pm 24 \\
76 \pm 16 \\
105 \pm 24 \\
* \\
4 \cdot 2 \pm 1 \cdot 6 \\
* \\
552 \pm 156 \\
84 \pm 38 \\
206 \pm 70 \\
262 \pm 100 \\
15 \cdot 6 \pm 5 \cdot 4 \\
-18 \pm 25 \cdot 7 \\
8 \cdot 4 \pm 2 \cdot 5 \\
-16 \cdot 2 \pm 24 \cdot 7 \\
9 \cdot 3 \pm 3 \cdot 6 \\
27 \cdot 9 \pm 29 \cdot 4 \\
0 \cdot 22 \pm 0 \cdot 04 \\
0 \cdot 31 \pm 0 \cdot 23 \\
0 \cdot 23 \pm 0 \cdot 24 \\
0 \cdot 23 \pm 0 \cdot 14 \\
0 \cdot 20 \pm 0 \cdot 25 \\
12 \cdot 3 \pm 5 \cdot 0\end{array}$ & $\begin{array}{c}201 \pm 7 \\
253 \pm 51 \\
151 \pm 12 \\
118 \pm 18 \\
17 \cdot 1 \pm 9 \cdot 7 \\
48 \pm 30 \\
81 \pm 11 \cdot 5 \\
122 \pm 11 \\
11 \cdot 8 \pm 2 \cdot 2 \\
3 \cdot 1 \pm 2 \cdot 4 \\
74 \pm 19 \\
613 \pm 58 \\
22 \pm 19 \\
230 \pm 57 \\
322 \pm 67 \\
21 \cdot 5 \pm 5 \cdot 2 \\
10 \cdot 9 \pm 26 \cdot 1 \\
14 \cdot 0 \pm 6 \cdot 6 \\
45 \cdot 2 \pm 66 \\
11 \cdot 3 \pm 2 \cdot 8 \\
76 \cdot 3 \pm 45 \cdot 9 \\
0 \cdot 26 \pm 0 \cdot 14 \\
0 \cdot 57 \pm 0 \cdot 28 \\
0 \cdot 51 \pm 0 \cdot 60 \\
0 \cdot 64 \pm 0 \cdot 38 \\
0 \cdot 42 \pm 0 \cdot 39 \\
23 \cdot 8 \pm 12 \cdot 7\end{array}$ & $\begin{array}{c}210 \pm 6 \\
231 \pm 40 \\
145 \pm 14 \\
132 \pm 21 \\
17 \cdot 6 \pm 7 \cdot 6 \\
51 \pm 25 \\
77 \pm 12 \\
113 \pm 16 \\
12 \cdot 1 \pm 2 \cdot 3 \\
3 \cdot 5 \pm 2 \cdot 4 \\
70 \pm 21 \\
399 \pm 42 \\
94 \pm 40 \\
121 \pm 27 \\
185 \pm 50 \\
15 \cdot 3 \pm 4 \cdot 9 \\
-13 \cdot 2 \pm 39 \cdot 8 \\
8 \cdot 6 \pm 3 \cdot 7 \\
-14 \cdot 7 \pm 44 \cdot 3 \\
9 \cdot 1 \pm 2 \cdot 1 \\
40 \cdot 5 \pm 34 \cdot 9 \\
0 \cdot 21 \pm 0 \cdot 07 \\
0 \cdot 38 \pm 0 \cdot 17 \\
0 \cdot 26 \pm 0 \cdot 20 \\
0 \cdot 35 \pm 0 \cdot 20 \\
0 \cdot 44 \pm 0 \cdot 22 \\
16 \cdot 0 \pm 5 \cdot 3\end{array}$ & $\begin{array}{c}208 \pm 7 \\
256 \pm 52 \\
143 \pm 12 \\
114 \pm 15 \\
32 \cdot 1 \pm 9 \cdot 1 \\
84 \pm 21 \\
66 \pm 10 \cdot 7 \\
105 \pm 10 \\
10 \cdot 9 \pm 2 \cdot 2 \\
5 \cdot 9 \pm 2 \cdot 0 \\
45 \pm 19 \\
586 \pm 55 \\
78 \pm 26 \\
228 \pm 70 \\
280 \pm 39 \\
13 \cdot 7 \pm 5 \cdot 1 \\
8 \cdot 4 \pm 3 \cdot 1 \\
\\
7 \cdot 3 \pm 1 \cdot 6 \\
0 \cdot 19 \pm 0 \cdot 06 \\
0 \cdot 33 \pm 0 \cdot 21 \\
0 \cdot 20 \pm 0 \cdot 22 \\
0 \cdot 26 \pm 0 \cdot 18 \\
0 \cdot 28 \pm 0 \cdot 27 \\
13 \cdot 2 \pm 6 \cdot 1\end{array}$ \\
\hline
\end{tabular}

* Not measured. 
in the infants on the other 3 feeds. Fat intake was not measured in the EBM group but it is worth noting that faecal fat was no lower in this group than in the others. Nitrogen intakes were fairly high on EBM, reflecting the higher $\mathrm{N}$ content of preterm mothers' milk. ${ }^{32}$ Nitrogen absorption from EBM was however no better than that of the other milks. The milk with the highest $\mathbf{N}$ content (Pre-Aptamil) gave the best $\mathbf{N}$ absorption and retention. $\mathrm{Ab}$ sorption of $\mathrm{N}$ from Osterfeed was comparable with that of EBM and Milumil, but $\mathbf{N}$ retention was significantly lower on this formula despite lower urine $\mathbf{N}$ losses. Thus the $\mathbf{N}$ content of this formula may not be sufficient for small preterm infants. In all the growth measurements except one (subscapular skinfold thickness) infants showed greatest increments on Pre-Aptamil. This trend reached statistical significance in many of the comparisons (Table 6). The improved nitrogen retention, linear growth, and head growth show that the infants were not simply depositing fat. Growth of infants on EBM was comparable with that of the group on Osterfeed. Blood urea was higher in infants on Pre-Aptamil and Milumil than on Osterfeed $(P<0.05)$, but not EBM. There were no significant differences in electrolytes or acid-base status (Table 7).

Table 6 Significant differences in nutritional and growth data in the groups of infants on the different feeds

\begin{tabular}{|c|c|c|c|}
\hline Measurement compared & Comparison groups & $t$ & $P<$ \\
\hline Energy intake (kcal/kg) & Pre-Aptamil $>$ EBM & $2 \cdot 2$ & 0.05 \\
\hline Stool weight & Milumil $>$ Pre-Aptamil & $2 \cdot 7$ & 0.05 \\
\hline \multirow[t]{3}{*}{ Faecal energy } & Milumil $>$ Pre-Aptamil & $2 \cdot 7$ & 0.05 \\
\hline & Milumil > Osterfeed & $2 \cdot 8$ & 0.05 \\
\hline & Milumil $>$ EBM & $3 \cdot 1$ & 0.01 \\
\hline Digestible energy & Pre-Aptamil $>$ Milumil & $2 \cdot 3$ & 0.05 \\
\hline Energy balance & Pre-Aptamil $>$ Milumil & $2 \cdot 7$ & 0.05 \\
\hline \multirow[t]{2}{*}{ Faecal fat } & Milumil-Pre-Aptamil & $2 \cdot 6$ & 0.05 \\
\hline & Osterfeed $>$ Milumil & $2 \cdot 3$ & 0.05 \\
\hline Fat absorption coefficient & Pre-Aptamil > Milumil & $2 \cdot 6$ & 0.05 \\
\hline Nitrogen intake (mg/kg) & Pre-Aptamil > Osterfeed & $8 \cdot 9$ & 0.001 \\
\hline \multirow{2}{*}{ Faecal nitrogen } & Osterfeed $>$ Pre-Aptamil & $4 \cdot 9$ & 0.001 \\
\hline & EBM $>$ Pre-Aptamil & $4 \cdot 3$ & 0.001 \\
\hline \multirow[t]{2}{*}{ Urinary nitrogen } & Pre-Aptamil $>$ Osterfeed & $5 \cdot 2$ & 0.001 \\
\hline & EBM $>$ Osterfeed & $3 \cdot \overline{2}$ & 0.01 \\
\hline \multirow[t]{3}{*}{ Retention of nitrogen } & EBM $>$ Osterfeed & $2 \cdot 2$ & 0.05 \\
\hline & Pre-Aptamil $>$ Osterfeed & $4 \cdot 9$ & 0.001 \\
\hline & Milumil $>$ Osterfeed & $4 \cdot 6$ & 0.001 \\
\hline \multirow[t]{3}{*}{ Weight gain $(g / k g)$} & Pre-Aptamil $>$ EBM & $2 \cdot 5$ & 0.05 \\
\hline & Pre-Aptamil $>$ Osterfeed & $3 \cdot 0$ & 0.01 \\
\hline & Pre-Aptamil $>$ Milumil & $2 \cdot 6$ & 0.05 \\
\hline Weight gain coefficient & Pre-Aptamil $>$ EBM & $2 \cdot 5$ & 0.05 \\
\hline \multirow[t]{3}{*}{ Length gain (mm/week) } & Pre-Aptamil $>$ EBM & $2 \cdot 5$ & 0.05 \\
\hline & Pre-Aptamil $>$ Osterfeed & $2 \cdot 5$ & 0.05 \\
\hline & Pre-Aptamil $>$ EBM & $2 \cdot 8$ & 0.01 \\
\hline Length gain coefficient & Pre-Aptamil $>$ Osterfeed & $2 \cdot 6$ & 0.05 \\
\hline \multirow[t]{3}{*}{ Head growth (mm/week) } & Pre-Aptamil $>$ Osterfeed & $2 \cdot 2$ & 0.05 \\
\hline & Pre-Aptamil $>$ Milumil & $2 \cdot \overline{7}$ & 0.05 \\
\hline & Pre-Aptamil $>$ EBM & $2 \cdot 8$ & 0.01 \\
\hline Head growth coefficient & Pre-Aptamil $>$ Osterfeed & $2 \cdot 1$ & 0.05 \\
\hline \multirow{2}{*}{ Arm circumference } & Pre-Aptamil $>$ Osterfeed & $2 \cdot 1$ & 0.05 \\
\hline & Pre-Aptamil $>$ EBM & $2 \cdot 2$ & 0.05 \\
\hline Triceps skinfold & Pre-Aptamil > Osterfeed & $2 \cdot 1$ & 0.05 \\
\hline Arm fat area & Pre-Aptamil $>$ EBM & $2 \cdot 4$ & 0.05 \\
\hline
\end{tabular}

Table 7 Metabolic blood measurements on the various feeds

\begin{tabular}{|c|c|c|c|c|}
\hline & $E B M$ & Pre-Aptamil & Osterfeed & Milumil \\
\hline $\begin{array}{l}\text { Blood urea } \\
(\mathrm{mmol} / \mathrm{l})\end{array}$ & $2 \cdot 9 \pm 2 \cdot 8$ & $5 \cdot 3 \pm 2 \cdot 3$ & $2 \cdot 3 \pm 2 \cdot 1$ & $5 \cdot 1 \pm 3 \cdot 4$ \\
\hline Capillary blood pH & $7 \cdot 33$ & $7 \cdot 30$ & $7 \cdot 32$ & $7 \cdot 29$ \\
\hline $\begin{array}{l}\text { Base excess } \\
(\mathrm{mmol} / \mathrm{l})\end{array}$ & $-2 \cdot 3$ & $-4 \cdot 0$ & $-2 \cdot 1$ & $-4 \cdot 2$ \\
\hline $\begin{array}{l}\text { Plasma sodium } \\
(\mathrm{mmol} / \mathrm{l})\end{array}$ & 131 & 137 & 134 & 135 \\
\hline
\end{tabular}

To assess the effect of weight, postconceptional age, and postnatal age on energy and nitrogen balance, correlation coefficients were calculated for all infants. These were as follows:

\begin{tabular}{|c|c|c|}
\hline Weight versus digestible energy & +0.09 & NS \\
\hline Weight versus $\mathrm{N}$ digestibility & +0.01 & NS \\
\hline Weight versus $\mathrm{N}$ retention & +0.09 & NS \\
\hline $\begin{array}{l}\text { Postconceptional age versus } \\
\text { digestible energy }\end{array}$ & $+0 \cdot 35$ & $<0.05$ \\
\hline $\begin{array}{l}\text { Postconceptional age versus } \\
\mathbf{N} \text { digestibility }\end{array}$ & -0.06 & NS \\
\hline $\begin{array}{l}\text { Postconceptional age versus } \\
\mathrm{N} \text { retention }\end{array}$ & $+0 \cdot 11$ & NS \\
\hline $\begin{array}{l}\text { Postnatal age versus } \\
\text { digestible energy } \\
\text { Postnatal age versus digestibility }\end{array}$ & $\begin{array}{l}+0.25 \\
+0.19\end{array}$ & $\begin{array}{l}\text { NS } \\
\text { NS }\end{array}$ \\
\hline Postnatal age versus $\mathrm{N}$ retention & $+0 \cdot 14$ & NS \\
\hline
\end{tabular}

Digestible energy was not correlated with nitrogen retention $(\mathrm{r}-0 \cdot 13)$.

\section{Discussion}

Study design and methods. The aim of the study was to make nutritional comparisons of preterm infants fed with breast milk and formulae. Most existing studies are unsatisfactory in this respect because the infants are not comparable (owing to variations in postconceptional and postnatal age at the time of study) or because the study periods are too short. The importance of this is shown in our measurements where, even though good matching was achieved between the groups, there was considerable variation in the results depending on whether they were compared as absolute values or as coefficients of standard growth during the same postconceptional time period. It is important that the problems of obtaining adequate comparison groups are recognised when interpreting the results of such studies. Crossover designs resolve some of the problems but new ones emerge-such as changing digestive function and growth potential due to maturation-which may cause even greater difficulties if adequate periods of growth are to be studied. 
General aspects of the balance results. Although the main purpose of the study was to compare feeds, some general comments on the energy and $\mathrm{N}$ balances can be made. Fourteen of the infants weighed $<1500 \mathrm{~g}$ at the time of the study. Data on very low weight infants are scarce and are particularly valuable. However, our values for energy digestibility and $\mathrm{N}$ retention were little different from those of the larger infants $(74.3$ compared with $77.4 \%$ and 246 compared with $255 \mathrm{mg} \mathrm{N} / \mathrm{kg}$ a day respectively). Thus weight alone is not of great significance in infants $>1000 \mathrm{~g}$ and was not found to be correlated with energy and nitrogen absorption. More data are needed on infants $<1000 \mathrm{~g}$. Surprisingly we were unable to demonstrate any important effect of postconceptional and postnatal age on nitrogen retention, although there was a significant improvement in energy digestibility with increasing postconceptional age.

If energy intake is low nitrogen retention is impaired because protein is used for energy. We could not show that improved energy balance resulted in greater $\mathbf{N}$ retention in our infants, indicating that at the time of the studies energy balance was not a limiting factor in the utilisation of protein for growth.

Comparison of feeds. Some specific points about the performance of the feeds are worth making. Breast milk varied greatly in composition. This makes it difficult to monitor energy and protein intakes in clinical practice, and is a problem that we and others have raised before. ${ }^{910}$ The fairly high $\mathrm{N}$ content did not reflect an equivalently high content of utilisable protein, since urine $\mathbf{N}$ losses were nearly twice as great as in the infants fed Osterfeed, whose protein content approximates mature human milk, and the proportion of $\mathbf{N}$ retained was about the same $(\sim 47 \%)$. It was notable also that energy digestibility was no better on human milk than on the formulae (with the exception of Milumil), and faecal fat excretion was similar. Although the digestibility of human milk fat is generally considered to be better than that of formulae, the properties of human milk may not entirely overcome the physiological handicaps of the very immature in relation to fat absorption, and heating also impairs the digestion of human milk fat. ${ }^{26}$ It may also impair $\mathrm{N}$ absorption or biological value since recent work in very immature infants has shown better $\mathrm{N}$ retentions on unheated human milk than we found. ${ }^{33}$ Infants fed human milk in our studies tended to grow the slowest.

Milumil, a formula designed for term infants, was unsuitable for the preterm despite its higher protein content. $\mathrm{N}$ retention was good but fat digestion poor. This may be due to its high saturated fat content
$(53.5 \%)$. A comparison with Osterfeed, also designed for term infants, is interesting. Fat absorption from Osterfeed was significantly better, but $\mathrm{N}$ absorption and retention were worse. Osterfeed has a 60:40 whey-casein ratio, compared with 20:80 in Milumil, and this whey-predominant protein, similar to human milk, is said to improve its digestibility. ${ }^{34}$ It does not appear to do so. The better fat absorption from Osterfeed is probably related to its high unsaturated fat content $(61 \%)$ and fairly low content of $\mathrm{C} 16$ and $\mathrm{C} 18$ in the $\alpha$ positions on the triglyceride molecule. ${ }^{35}$

The infants grew fastest on Pre-Aptamil. This formula, providing a modest increase in energy density and a higher protein content, gave the best results on all the measured nutritional parameters. The variability of these measures is such that it is difficult to show significant differences without large numbers. Nevertheless the main differences between Pre-Aptamil and the other milks appeared to be in protein rather than energy nutrition, and the increase in linear growth on this formula is worth comment. It is possible that other nutrients may have contributed to the increased growth, for example sodium, and we cannot be certain which were the most important factors. It is often stated that growth should not be considered the only (or even the main) criterion of feed performance, and it cannot be denied that survival is the first priority. However, with modern neonatal care the type of feeding has not been shown to influence survival. From a purely nutritional viewpoint good growth should be the main criterion of success, and there seems no reason not to aim for the best possible rate, at least until this has been shown to be undesirable. There is certainly no justification in using intrauterine growth rate as the standard to aim for, since postnatal growth is qualitatively quite different. ${ }^{36}$ Neither is there any justification for saying that the slower growth of preterm infants on EBM is more desirable than the faster growth of infants on specially adapted formulae. If such growth were principally in fatness, and fat accretion rates may certainly be higher, ${ }^{37}$ there would be legitimate concern about later obesity, but there is no evidence that formula-fed preterm infants become unduly fat later, ${ }^{38}$ and our data show that linear measurements and head growth are improved with the use of a suitable formula.

We believe that it is reasonable to aim for maximum growth in preterm infants, since this is likely to be limited only by genetic potential so long as the necessary substrates are provided. It may be easier to achieve this on a formula than on breast milk. Atkinson et al. ${ }^{33}$ have demonstrated marginally better growth and improved nutritional balances in infants on mother's own milk than in those on 
banked milk, but we regard the variability of mother's own milk as a major disadvantage in day-to-day care of small infants. There are immunological and emotional arguments in favour of breast milk but we see the nutritional aspects of feeding as more important.

\section{References}

1 Addy D P. Infant feeding: a current view. Br Med J 1976; i: $1268-71$.

2 Räihä N C R, Heinonen K, Rassin D K, Gaull G E. Milk protein quantity and quality in low birthweight infants. 1. Metabolic responses and effects on growth. Pediatrics 1976; 57: 659-74.

3 Schultz K, Soltész G, Mestyán J. The metabolic consequences of human milk and formula feeding in premature infants. Acta Paediatr Scand 1980; 69: 647-52.

4 Department of Health and Social Security. The collection and storage of human milk. Report on Health and Social Subjects No 22. London: HMSO, 1981.

5 Jelliffe D B. Unique properties of human milk: remarks on some recent developments. J Reprod Med 1975; 14: 133-7.

- Hanson L $\AA$, Winberg J. Breast milk and defence against infection in the newborn. Arch Dis Child 1972; 47: 845-8.

7 Barlow B, Santulli T V, Heird W C, Pitt J, Blanc W A, Schullinger $J \mathbf{N}$. An experimental study of acute neonatal enterocolitis: the importance of breast milk.J Pediatr Surg 1974; 9: 587-94.

8 Shaw J C L. Evidence for defective skeletal mineralization in low birthweight infants; the absorption of calcium and fat. Pediatrics 1976; 57: 16-25.

- Tyson J, Lasky R, Mize C, White R. Growth and development of infants less than $1500 \mathrm{~g}$ fed bank human milk or premature formula (abstract). Pediatr Res 1981 ; 15: 549.

10 Carroll L, Conlan D, Davies D P. Fat content of bank human milk (abstract). Arch Dis Child 1980; 55: 969.

11 Hibberd C, Brooke O G, Carter N D, Wood C. A comparison of protein concentrations and energy in breast milk from preterm and term mothers. $J$ Hum Nutr 1981 ; 35: 189-98.

12 Davies D P. Adequacy of expressed breast milk for early growth of preterm infants. Arch Dis Child 1977; 52: 296-301.

13 Fomon S J, Ziegler E E, Vásquez H D. Human milk and the small premature infant. Am J Dis Child 1977; 131: 463-7.

14 Zimmerman A W, Hambridge M, Lepow M L, Greenberg R D, Stover M L, Casey C E. Acrodermatitis in breast-fed premature infants. Pediatrics 1982; 68: 176-83.

15 Hibberd C M, Brooke O G, Brown I R F, Carter N D, Wood C A. Is preterm milk nutritionally advantageous? Am J Clin Nutr 1981; 34: 1154-5.

16 Jackson A A, Shaw J C L, Barber A, Golden M H N. Nitrogen metabolism in preterm infants fed human donor breast milk: the possible essentiality of glycine. Pediatr Res 1981; 15: 1454-61.

17 Dubowitz L M, Dubowitz V, Goldberg C. Clinical assessment of gestational age in the newborn infant. J Pediatr 1970; 77: 1-10.

18 Gairdner D, Pearson J. A growth chart for premature and other infants. Arch Dis Child 1971; 46: 783-7.

19 Watkins J B. Mechanisms of fat absorption and the development of gastrointestinal function. Pediatr Clin $N$ Am 1975; 22: 721-30.
${ }^{20}$ Brooke $O$ G. Energy balance and metabolic rate in $ح$ preterm infants fed with standard and high energy $\overline{\bar{Q}}$ formulas. BrJ Nutr 1980; 44: 13-23.

21 ESPGAN Committee on Nutrition. Guidelines on infant nutrition. Acta Paediatr Scand 1977; Supplement 262.

22 American Academy of Pediatrics Committee on Nutrition. Nutritional needs of low-birthweight infants. Pediatrics 1977; 60: 519-30.

23 Miller D S, Payne P R. A ballistic bomb calorimeter. BrJ Nutr 1959; 13: 501-4.

24 Lemoh N, Brooke O G. Frequency and weight of normal stools in infancy. Arch Dis Child 1979; 54: 719-20.

25 Pencharz P B, Steffee W P, Cochran W, Scrimshaw N S, $\vec{O}$ Rand W M, Young V R. Protein metabolism in human neonates: nitrogen balance studies, estimated obligatory $\vec{\omega}$ losses of nitrogen, and whole body turnover of nitrogen. Clin Sci Molec Biol 1977; 52: 485-98.

26 Williamson S, Finucane E, Ellis H, Gamsu H R. Effect of heat treatment of human milk on absorption of nitrogen, $G$ fat, sodium, calcium, and phosphorus by preterm infants. . Arch Dis Child 1978; 53: 555-63.

27 Tanner J M, Whitehouse R H, Takaishi M. Standards $\infty$ from birth to maturity for height, weight, height velocity, and weight velocity. Arch Dis Child 1966; 41: 454-71.

28 Brooke O G, Butters F, Wood C, Bailey P, Tukmachi F. 윽 Size at birth from 37-41 weeks' gestation: ethnic standards for British infants of both sexes. J Hum Nutr 1981; 35: 415-30.

29 Tanner J M, Whitehouse $\mathbf{R} \mathbf{H}$. Revised standards for $\Phi$ triceps and subscapular skinfolds in British children. Arch Dis Child 1975; 50: 142-5.

30 Forbes G B. Body composition in adolescence. In: Falkner F, Tanner J M, eds. Human growth. Vol. 8 Postnatal growth. London: Bailliere Tindall, 1978: 251. 으

31 Lubchenco $L O$, Hansman $C$, Dressler $M$, Boyd Intrauterine growth as estimated from live-born birtlof weight data at $24-42$ weeks' gestation. Pediatrics $1963 ; 32$ : 793-800.

32 Atkinson S A, Bryan M H, Anderson G H. Human milk: difference in nitrogen concentration in milk from mothers of term and premature infants. J Pediatr 1978; 93: 67-9.

33 Atkinson S A, Bryan M H, Anderson G H. Human milk feeding in premature infants: protein, fat, and carbo- $O$ hydrate balances in the first two weeks of life. $J$ Pediatr 1981; 99: 617-24.

34 Tomarelli R M, Bernhart F W. Biological assay of milk and whey protein composition for infant feeding. $J$ Nutr 1962; 78: 44-50.

35 Filer L J, Mattson F H, Fomon S J. Triglyceride configuration and fat absorption by the human infant. $J$ Nutr 1969; 99: 293-8.

36 McIntosh N, Shaw J C L, Taghizadeh A. Accumulation of nitrogen and collagen in the femur of the human foetus and the effect of premature birth (abstract). Pediatr Res 1977; 11: 1023.

37 Reichman B, Chessex P, Putet G, et al. Diet, fat accretion, and growth in premature infants. $N$ Engl J Med 1981; 305: 1495-500.

38 Brandt I. Growth dynamics of low-birth-weight infants $\mathrm{N}$ with emphasis on the perinatal period. In: Falkner F, S Tanner J M, eds. Human Growth. Vol. 2. Postnatal N growth. London: Bailliere Tindall, 1978: 557.

Correspondence to Dr O G Brooke, Department of Child Health, St George's Hospital Medical School, Cranmer Terrace, London SW17 ORE.

Received 18 August 1982 